\title{
Estimation of rock mass mechanical parameters of an open-pit mine slope based on the Hoek-Brown criterion and analysis of slope stability LIAN Baoqin1, *WANG Xingang1,2
}

1.College of Geology Engineering and Geomatics, Chang'an University, Xi'an 710054, China;

2.State Key Laboratory of Continental Dynamics, Department of Geology, Northwest University, Xi'an 710069, China.

${ }^{*}$ corresponding author

\begin{abstract}
KEYWORD: Slope; Mechanical parameters; Numerical simulation; Stability analysis
ABSTRACT: How to select scientific and reasonable mechanical parameters of rock mass is particularly important to evaluation of slope stability. Based on the collection of engineering geological data about a mine, and through detailed survey and analysis of the engineering geological conditions in the field, the Hoek-Brown strength criterion was used to estimate the rock mass strength parameters of this mine. Finally, a numerical simulation model for the open-pit mine slope was established; the finite difference method was employed for numerical calculation of the slope stability; the rule of changes in displacement field, plastic zone and shear strain was analyzed; the stability of open-pit mine slope was analyzed and evaluated. These provide a basis for design and safe production of the mine.
\end{abstract}

\section{INTRODUCTION}

The rapid increase of world population has resulted in the increasing demand for mineral resources; therefore, slope stability associated with open-pit mining has become a serious issue threatening the entire mining area (Hakan et al., 2013). The issue of slope stability in open-pit mining substantially concerns the selection of mechanical parameters of slope rock mass, but the inhomogeneity and nonlinearity characteristics of rock mass lead to the uncertainty and randomness in selection of mechanical parameters of rock mass (Whitman et al., 2000; Babu et al.,2004; Moradi et al., 2014). The accuracy of slope analysis results largely depends on the selection of mechanical parameters of rock mass. Just as the concept of "Garbage in, garbage out" put forward by Professor J. A. Hudson (1993), how to select scientific and reasonable mechanical parameters of rock mass is of great significance for guaranteeing the design and safe operation of slope engineering (Masoud et al., 2013, Wang et al., 2015, M. Francioni et al., 2015).

Huangshan limestone mine slope in China was taken as the research object. Through survey and analysis of the development level of rock mass structural plane and the characteristics of engineering geological rock group, the Hoek-Brown rock mass strength criterion was used to estimate the mechanical parameters of rock mass in this mine. Finally, the finite difference software FLAC3D was used to analyze and evaluate the slope stability of II-II principal section of this mining area, thus to provide technical support for its safe mining.

\section{PROJECT OVERVIEW}

Huangshan limestone mine area is located in the low to middle-low mountainous area at the margin of Sichuan Basin in China. Fig. 1 shows local area of the mine site. In this mine area, Permian limestone and sandstone are mainly exposed, and multi-weak interlayers exist in its strata, which mainly consist of carbon-containing argillaceous limestone and clay-containing sandy limestone; a single weak interlayer is $0.10 \sim 8.34 \mathrm{~m}$ thick as shown in fig. 2 . 


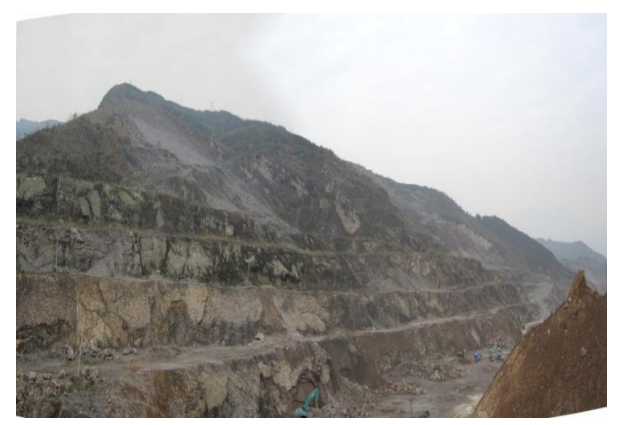

Fig. 1 Local area of mine site

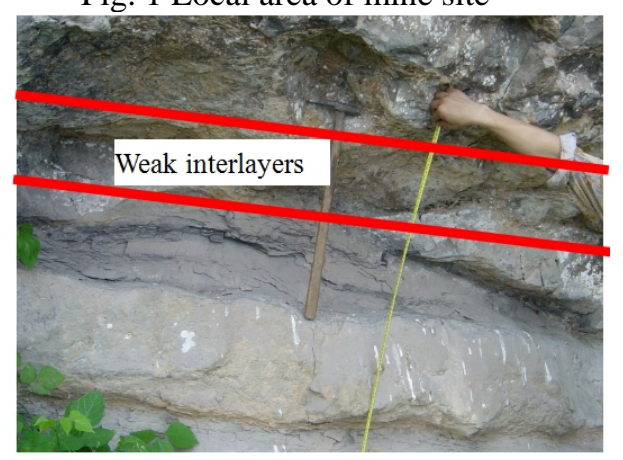

Fig. 2 Weak interlayers

\section{APPLICATION OF THE HOEK-BROWN CRITERION}

Hoek and Brown, after a systematic research on the parabolic failure envelopes of plenty of rocks, came up with the Hoek-Brown empirical failure criterion - Hoek-Brown strength criterion (Hoek E et al., 2002; Thomas Bet al., 2008):

$$
\begin{gathered}
\sigma_{1}^{\prime}=\sigma_{3}^{\prime}+\sigma_{c i}\left(m_{b} \frac{\sigma_{3}^{\prime}}{\sigma_{c i}}+s\right)^{a} \\
m_{b}=m_{i} \exp \left(\frac{G S I-100}{28-14 D}\right) \\
s=\exp \left(\frac{G S I-100}{9-3 D}\right) \\
a=\frac{1}{2}+\frac{1}{6}\left(e^{-G S I / 15}-e^{-20 / 3}\right)
\end{gathered}
$$

Where: $\sigma_{1}^{\prime}$ and $\sigma_{3}^{\prime}$ are respectively the maximum and minimum principal effective stresses under the circumstance of rock mass failure; $\sigma_{c i}$ is the uniaxial compressive strength of rock; $m_{b}, s$ and $a$ are material parameters associated with the characteristics of rock mass; $m_{i}$ is the $m$ value of complete rock; GSI is the geological strength index of rock mass (please refer to the research of E. Hoek et al (2002) as to how to determine the value of this parameter); D is the stress disturbance coefficient, the value of which is within the range of $0 \sim 1$ (the value is 0 for slope engineering). Based on quality evaluation of the open-pit mine slope rock mass of Huangshan limestone mine, the structural characteristics of slope rock mass and the characteristics of engineering geological rock group were considered and the statistical results of structural plane measurement in the field were combined to quantify SC and SCR in the GSI evaluation system, further to determine the value of GSI. The uniaxial compressive strength of rock was determined according to the results of indoor rock mechanical test. The value of mi was determined according to the descriptions about rocks of different lithologic characters by the Hoek-Brown criterion. After obtaining the above parameters, the Hoek-Brown criterion was used to estimate the mechanical parameters of slope rock mass in different zones. Table 1 lists the strength and deformation indexes obtained for the slope rock mass. 
Table 1 Strength parameters of slope rock mass calculated with the Hoek-Brown criterion

\begin{tabular}{|c|c|c|c|c|c|c|c|c|c|}
\hline \multicolumn{2}{|c|}{ Lithology } & GSI & $\sigma_{t}(\mathrm{MPa})$ & $\mathrm{mi}$ & D & $c(\mathrm{MPa})$ & $\varphi\left({ }^{\circ}\right)$ & $\mathrm{E}(\mathrm{GPa})$ & $\sigma_{i}(\mathrm{MPa})$ \\
\hline \multicolumn{2}{|c|}{ Weak interlayer } & 17 & 20 & 5 & 0 & 0.03 & 24.48 & 0.67 & 0.008 \\
\hline \multicolumn{2}{|c|}{$\begin{array}{c}\text { Sandstone in } \\
\text { Dachengsi Group }\end{array}$} & 57 & 110 & 13 & 0 & 3.82 & 42.11 & 14.96 & 0.31 \\
\hline \multirow{3}{*}{$\begin{array}{l}\text { Limesto } \\
\text { ne }\end{array}$} & $\begin{array}{c}\text { Zone } \\
\text { I }\end{array}$ & 45 & 109 & 12 & 0 & 1.93 & 43.54 & 7.45 & 0.14 \\
\hline & $\begin{array}{l}\text { Zone } \\
\text { II }\end{array}$ & 40 & 109 & 12 & 0.5 & 1.26 & 36.68 & 4.2 & 0.05 \\
\hline & $\begin{array}{c}\text { Zone } \\
\text { III }\end{array}$ & 37 & 109 & 12 & 0.7 & 1.03 & 31.01 & 3.07 & 0.03 \\
\hline
\end{tabular}

\section{ESTABLISHMENT OF ENGINEERING GEOLOGICAL NUMERICAL MODEL}

The II - II' principal section in Huangshan limestone mine area was chosen for numerical simulation calculation, as shown in Fig. 3. The lowest and highest mining elevations on this section are $+640 \mathrm{~m}$ and $+1,229 \mathrm{~m}$, respectively; the "top-down horizontal stratification" mining mode is applied; the height of step slope is $15 \mathrm{~m}$, and the final slope angle is $17.58^{\circ}$. The pre-processing function of the finite element software ANSYS was used to establish the II - II ' section computation model; factors such as boundary conditions and stratum elements of the slope were fully considered; fine cell processing was adopted, with 5,000 grid cells and 10,148 nodes divided. Then, the model was imported into FLAC3D, as shown in Fig. 4.

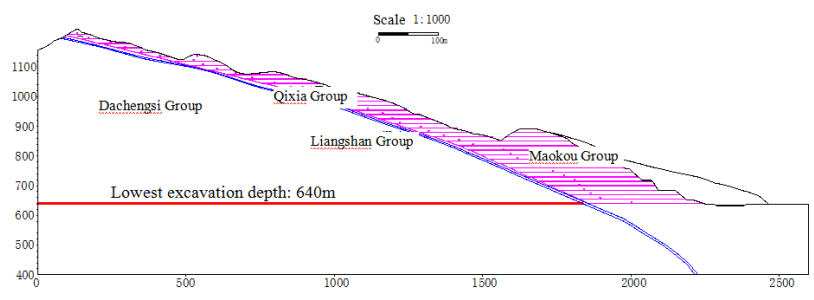

Fig. 3 II - II ' mining section

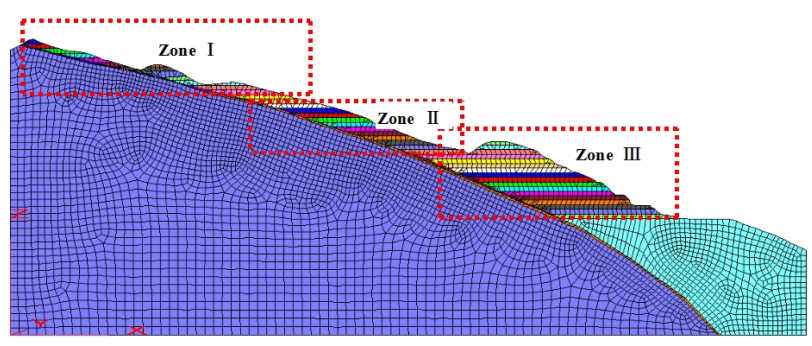

Fig. 4 II - II ' section computation model (the bottom face of the model adopts full constraint; the left and right boundaries constrain X-displacement; the top face is a free face)

\section{NUMERICAL ANALYSIS OF SLOPE EXCAVATION STABILITY}

Based on numerical simulation calculation for slope excavation of Huangshan limestone open-pit mine, the horizontal displacement field, shear strain increment and plastic zone of the slope were analyzed. The calculated results are shown in Fig. 5 to 7. 


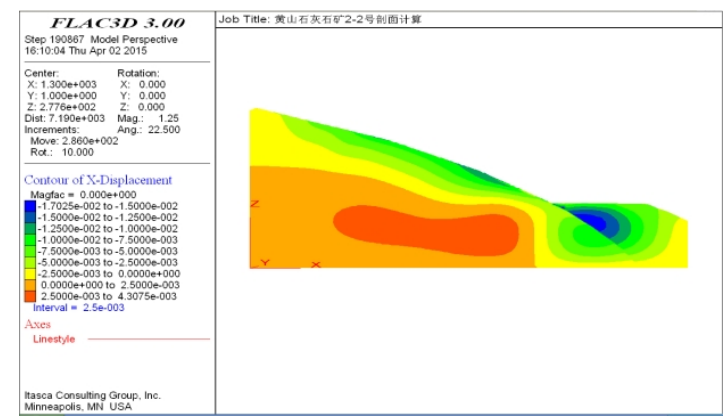

Fig. 5 Contour of horizontal displacement field of the slope

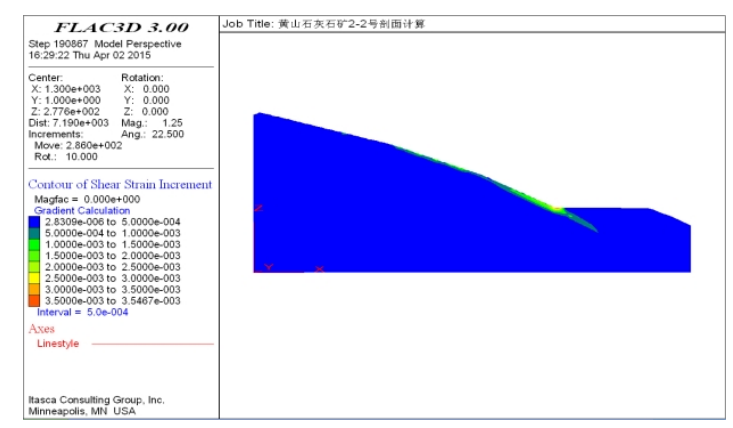

Fig. 6 Contour of shear strain increment

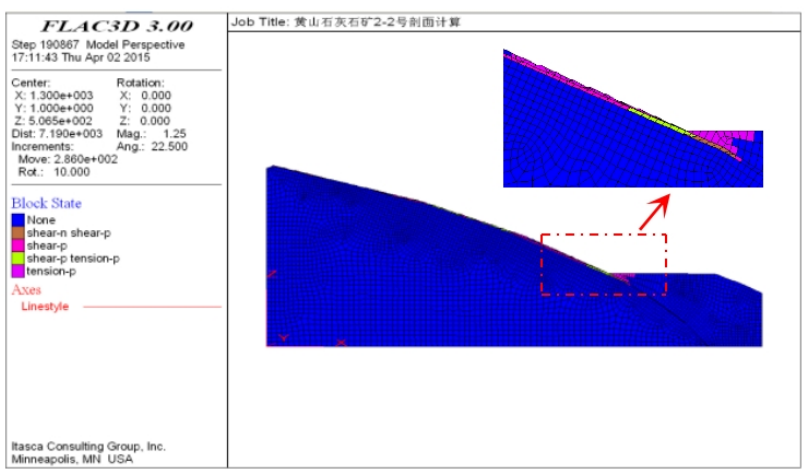

Fig. 7 Plastic zone of the slope

As can be seen from Fig. 5, the maximum displacement after slope excavation is $4.31 \mathrm{~mm}$. According to Fig. 6, the maximum shear strain increment of the slope is $3.55 \times 10-3$; the area of shear strain increment expands along the entire slope excavation face, forming potential sliding failure mass. As can be seen from Fig. 7, a certain area of plastic shear zone exists at the excavation slope toe, and the weak interlayers have relatively continuous shear and tension failure zones. Therefore, the sandstone on the slope surface may slide along the weak interlayers, and such sliding poses great hazards; from the perspective of long-term stability of the slope, it is suggested to eliminate the weak interlayers.

\section{CONCLUSION}

Based on the collection of engineering geological data about Huangshan limestone mine, and through detailed survey and analysis of the engineering geological conditions in the field, the HoekBrown strength criterion was used to estimate the strength parameters of rock mass in this mine, thus to provide reference for determining the values of mechanical parameters of rock-soil mass in similar projects. 
The finite difference method was employed for numerical calculation of the slope stability on the principal section of this mine; the rule of changes in displacement field, plastic zone and shear strain was analyzed; the stability of open-pit mine slope was analyzed and evaluated. These provide a basis for design and safe production of the mine.

The sandstone on the slope surface may slide along the weak interlayers, and such sliding poses great hazards; therefore, it is suggested to eliminate the weak interlayers because they can be quite threatening as potential sliding mass.

\section{ACKNOWLEDGEMENTS}

These research results are supported by the Opening Foundation of State Key Laboratory of Continental Dynamics No. 201210126, Natural Science Basic Research Plan in Shaanxi Province of China (Program No. 2016JQ4014)" ,Northwest University and the Opening Foundation of Key Laboratory for Geo-hazards in Loess area,MLR No,KLGLAMLR201505.

\section{REFERENCES}

[1] Hakan Tanyas, Resat Ulusay. Assessment of structurally-controlled slope failure mechanisms and remedial design considerations at a feldspar open pit mine, Engineering Geology, Vol,155, 2013, P. 54-68.Hudson J . A . (Ed . )Com Prehensive rock engineering[M] . London : PergamonPress, 1993.

[2] Babu GLS, Mukesh MD. Effect of soil variability on reliability of soil slopes. Geotechnique , 2004, Vol,545,P.35-7. Whitman RV. Organizing and evaluating in geotechnical engineering. J Geotech Geoenviron Eng 2000;1267:583 - 93.

[3] Wang Xingang, Hu Bin, Wang Jiading. Quantitative study of Hoek-Brown strength criterion based on GSI, Chinese Journal of Rock Mechanics and Engineering, 2015,S2, p.3805-3812.

[4] Moradi Afrapoli Ali, Osanloo Morteza, Determination and stability analysis of ultimate open-pit slope under geomechanical uncertainty, International Journal of Mining Science and Technology, Vol ,24(1), 2014, P.105-110.

[5] Masoud Zare Naghadehi, Rafael Jimenez, Reza KhaloKakaie, Seyed-Mohammad Esmaeil Jalali, A new open-pit mine slope instability index defined using the improved rock engineering systems approach, International Journal of Rock Mechanics and Mining Sciences, Vol,61, 2013, P. 1-14.

[6] M. Francioni, R. Salvini, D. Stead, R. Giovannini, S. Riccucci, C. Vanneschi, D. Gullì, An integrated remote sensing-GIS approach for the analysis of an open pit in the Carrara marble district, Italy: Slope stability assessment through kinematic and numerical methods, Computers and Geotechnics, Vol,67, ,2015, P.46-63.

[7] Hoek E, Carranza-torres C, Corkum B. Hoek-Brown failure criterion-2002 edition[C]// AMMAHW, CURRAN B J, TELESNICKI M, ed. Proceedings of NARMS - TAC2002, Mining Innovation and Technology. Toronto: [s. n.], 2002,p.267 - 273.

[8] Thomas B, Radu S,Regina. A. K,et al. Hoek-Brown criterion with intrinsic material strength factorization[J]. International Journal of Rock Mechanics and Mining Sciences, 2008,45(2):210222. 